\title{
ERRATUM
}

Manori J. Silva · Dana B. Barr · John A. Reidy

Kayoko Kato · Nicole A. Malek · Carolyn C. Hodge

Donald Hurtz III $\cdot$ Antonia M. Calafat

Larry L. Needham · John W. Brock

\section{Glucuronidation patterns of common urinary and serum monoester phthalate metabolites}

Published online: 13 April 2005

(C) Springer-Verlag 2005

\section{Arch Toxicol (2003) 77:561-567}

Page 565, second column, second paragraph should read: The percentage of free $\mathrm{mEP}, \mathrm{mBP}, \mathrm{mBzP}$ and
$\mathrm{mEHP}$ found in urine remained scattered with geometric means $71,6,7$ and $16 \%$ respectively, and showed no apparent increase with increased concentration of total phthalate as should occur if enzyme saturation occurred.

The online version of the original article can be found at http:// dx.doi.org/10.1007/s00204-003-0486-3

M. J. Silva $(\bowtie) \cdot$ D. B. Barr · J. A. Reidy $\cdot$ K. Kato

N. A. Malek · C. C. Hodge · A. M. Calafat · L. L. Needham

J. W. Brock

Division of Laboratory Sciences, National Center

for Environmental Health, Centers for Disease Control

and Prevention, 4770 Buford Hwy NE, Mailstop F17,

Atlanta, GA 30341, USA

E-mail: zca2@cdc.gov

Tel.: + 1-770-4887982

Fax: + 1-770-4884609

D. Hurtz III

Battelle Memorial Institute, Edgewood Operations, 2012 Tollgate Road, Suite 206, Bel Air, MD 21015, USA 